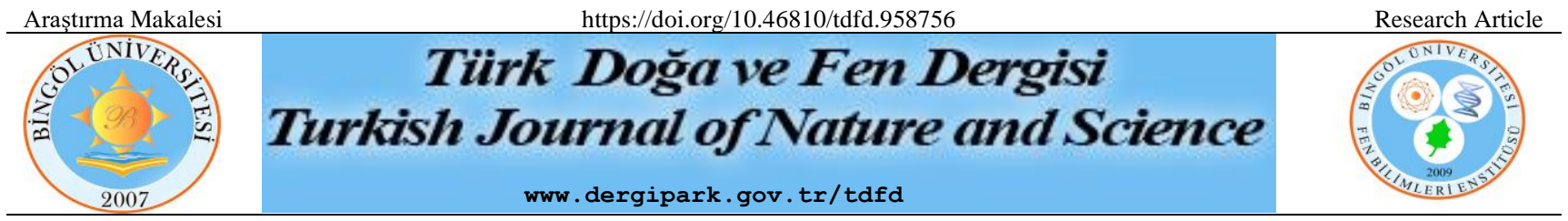

\title{
İfosfamid ve Kurkumin Kombinasyonun Küçük Hücreli Dışı Akciğer Kanseri Hücresinde Apoptotik Biyobelirteçler ve Hücre Göçü Üzerine Etkileri
}

\author{
Dursun ÖZDEMIIR ${ }^{1}$, Kemalcan ŞATANA $^{1}$, Deniz ÖZDEMİR ${ }^{1}$, Mehmet ÇiFTCI் $^{2}$, Can Ali AĞCA ${ }^{1 *}$ \\ ${ }^{1}$ Bingöl Üniversitesi, Fen-Edebiyat Fakültesi, Moleküler Biyoloji ve Genetik Bölümü, Bingöl, Türkiye \\ ${ }^{2}$ Bingöl Üniversitesi, Fen-Edebiyat Fakültesi, Kimya Bölümü, Bingöl, Türkiye \\ Dursun ÖZDEMIR ORCID No: 0000-0002-1233-7191 \\ Kemalcan ŞATANA ORCID No: 0000-0002-9498-3655 \\ Deniz ÖZDEMIR ORCID No: 0000-0001-7659-742X \\ Mehmet ÇIFTCİ ORCID No: 0000-0002-1748-3729 \\ Can Ali AĞCA ORCID No: 0000-0002-0244-3767
}

*Sorumlu yazar: caagca@bingol.edu.tr

(Alınış: 28.06.2021, Kabul: 20.12.2021, Online Yayınlanma: 31.12.2021)

\begin{abstract}
Anahtar
Kelimeler

İfosfamid,

Kurkumin,

A549,

Apoptozis,

Hücre göçü

Öz: Akciğer kanseri, dünyada kansere bağlı en fazla ölüme neden olan kötü huylu ve saldırgan tümörlerden biridir. İfosfamid, akciğer kanserinin de dâhil olduğu birçok kanser tedavisinde kullanılan alkilleyici bir antineoplastik ajandır. Curcuma longa rizomundan elde edilen bir flavonoid olan Kurkumin'in, insan kanserlerinde hücre büyümesinin inhibisyonu, hücre döngüsü dudurulması ve proapoptotik etki yoluyla kemoterapötik aktiviteye sahip olduğu gösterilmiştir. Bununla birlikte, ifosfamid ve kurkumin kombinasyonunun, küçük hücreli olmayan akciğer kanseri (NSCLC) üzerindeki etkileri henüz doğrudan ele alınmamıştır. Bu çalışmada akciğer kanseri hücre hattı A549'da, ifosfamid ve kurkumin kombinasyonunun, hücre proliferasyonu, hücre içi ROS birikimi, apoptozis ve hücre göçü üzerine olan etkileri gerçek-zamanlı hücre analizi, DCFDA floresan işaretleme, western blot ve yara iyileşme-hücre göçü testleri ile araştırılmıştır. A549 hücrelerinde İfosfamid-kurkumin kombinasyonu ile tedavi sonrasında, hücre içi ROS birikiminde ve pro-apoptotik Bax proteinin düzeyinde bir artış olduğu belirlendi. Ayrıca kombinasyonun tedavi edilmeyen ve tek ajan ile tedavi edilen hücrelere kıyasla, anti-apoptotik TIGAR protein düzeyinin azalmasında ve çizilen alana hücre göçünün bastırılmasında etkili olduğu belirlendi. Bulgularımız, Kurkumin'in küçük hücreli olmayan akciğer kanseri hücre hattın A549'da İfosfamidin etkinliğini artırdığını göstermektedir.
\end{abstract}

\section{Effects of Ifosfamide and Curcumin Combination on Apoptotic Biomarkers and Cell Migration in Non-Small Cell Lung Cancer Cell}

\begin{abstract}
Keywords Ifosfamide, Curcumin, A549, Apoptosis, Cell migration

Abstract: Lung cancer is one of the most common malignancies and aggressive tumour, which causes the highest cancer-related death in the world. Ifosfamide is an alkylating antineoplastic agent used in the treatment of cancer including, lung cancer. Curcumin, a flavonoid from the rhizome of Curcuma longa has been shown to chemotherapeutic activity through inhibition of cell growth, cell cycle arrest, and pro-apoptotic activity in human cancer. However, the effects of Ifosfamide and Curcumin combination on non-small cell lung cancer (NSCLC) remain unclear. In this study, the influences of Ifosfamide, cell proliferation, ROS accumulation, apoptosis, migration, and its combined effects with curcumin were investigated in NSCLC cell line A549 by RT-Cell analyse, DCFDA assay, western blot and wound healing-migration assays. A549 cells were treated with the Ifosfamide-Curcumin combination and the results showed that the combination was effective in ROS accumulation, which contributed to inducing apoptosis via increasing pro-apoptotic Bax and decreasing anti-apoptotic TIGAR, and depression of cell migration. The treatment of combination significantly induced apoptosis, together with the downregulation of TIGAR and upregulation of pro-apoptotic Bax protein. Moreover, Curcumin and Ifosfamide combination suppressed cell migration into the scratched area as compared to untreated cells. Our findings suggest that Curcumin enhanced the efficacy of Ifosfamide in human non-small cell lung cancer cell line.
\end{abstract}




\section{GİRIŞ}

Son yıllarda gelişmiş ülkelerde akciğer kanserinin görülme sıklığı önemli ölçüde artış göstermiş ve buna bağlı olarak ölümlerin önde gelen nedeni haline dönüşmüştür. Globocan (Global Cancer Observatory) verilerine göre, en çok tanı konulan kanserlerin başında $>\% 11$ ile akciğer kanseri yer almaktadır. Aynı zamanda, erkekler arasında en sık görülen kanserdir ve kanserden ölümlerin başlıca nedeni olarak gösterilmektedir [1]. Erken teşhis ve tedavilerinde büyük gelişmeler elde edilmiş olmasına rağmen, akciğer kanseri için prognoz hala zayıftır ve beş yılda tahmini hayatta kalma oranı sadece \% 15'tir [2]. Bu nedenle, akciğer kanseri hastaları için etkin bir tedavi acil bir ihtiyaçtır. Kanser için tedaviler arasında cerrahi müdahale, radyasyon, kemoterapi, hedefe yönelik tedavi ve immünoterapi yer alırken, kemoterapi en önemli tedavilerden biri olmaya devam etmektedir [3]. Paklitaksel, cisplatin, 5florourasil, siklofosfamid ve doksorubisin gibi kanser tedavisinde çok sayıda kemoterapötik ilaç geliştirilmiş ve kullanılmıştır [4-7]. Ancak kemoterapi'nin monoterapi olarak etkinliği, özellikle ilaç direnci nedeniyle kanser tedavisinde sınırlı kalmaktadır [6], [8]. $\mathrm{Bu}$ nedenle, farklı mekanizmalar ile etki gösteren kemoterapötik ilaçların kombinasyonu, kanser tedavisi için yaygın klinik uygulama haline gelmiştir [9-11]. İfosfamid, katı tümörler ve hematolojik maligniteler dâhil olmak üzere farklı tipte malignitelerin tedavisinde yaygın olarak kullanılan alkilleyici antineoplastik bir ajandır [12], [13]. İfosfamid, alkilleyici ajanların kemik iliği ve normal dokular üzerinde yan etkilere neden olmasına rağmen, kombinasyon tedavilerinde kemoterapinin önemli bir parçası olarak kullanılmaya devam etmektedir [14], [15]. İfosfamid, 4-hidroksilasyon yoluyla izofosforamid ve akrolein (Acr) üretir [16]. Acr, siklofosfamid ve ifosfamidin önemli bir metabolitidir ve bu antitümör ilaçların göstermiş olduğu sitotoksisitenin en önemli nedeni arasında gösterilmektedir [17]. Ancak Acr ve izofosforamid, indüklenebilir nitrik oksit sentazını aktive ederek nitrik oksit üretimine yol açar ve bu sayede reaktif oksijen türlerinin (ROS) yukarı regülasyonunu sağlayarak hücre ölümüne neden olur. ROS'daki artış proinflamatuar sitokin (tümör nekroz faktörü-alfa [TNF- $\alpha$ ] ve interlökin-1beta [IL-1 $\beta]$ ) gen ekspresyonunu uyaran aktivatör protein (I) gibi transkripsiyon faktörlerini indükler devamında ise DNA zincirlerini kırarak DNA hasarına neden olduğu bildirilmiştir [16, 18]. Issels ve ark. [19], insan periferik kan lenfositlerinde (PBL) IFO'nun hücre içi glutatyon (GSH) düzeyini azalttığını rapor etmişlerdir. Bir hücre içi tiyol indirgeyici olan GSH, alkilleyici ajanların sitotoksisitesine karşı normal ve tümör hücrelerini korumada önemli bir rol oynamaktadır. Aslında GSH, toksik metabolitlere, özellikle Acr'e geri çevrilemez şekilde bağlanarak hücre içi GSH içeriğinin önemli ölçüde tükenmesine yol açmaktadır. Hem doğrudan hem de dolaylı olarak enzim aktivasyonu, DNA ve protein sentezi, oksidatif hasardan korunma, hücresel redoks potansiyelinin sürdürülmesi ve hücre döngüsü gibi birçok biyolojik fonksiyonla ilgili olduğu kanıtlanmıştır [13]. Ayrıca IFO'nun sitotoksik etki göstermesine neden olan Acr'nin p53 bağımlı ve bağımsız programlı hücre ölümü apoptozisi aktive ettiği bildirilmiştir [17]. Zerdeçalın önemli bir bileşeni olan Kurkumin [1,7-bis(4hydroxy-3-methoxyphenyl)-hepta-1,6-diene-3,5dione] anti-inflamatuar [20], antioksidan [21] ve antikanser [22] özellikleri de dâhil olmak üzere çeşitli biyolojik etkiler gösterebilen doğal bir fenoldür. Kurkumin, Hint tıbbında iltihaplanma ve ağnı gibi durumlar için bir tedavi seçeneği olarak yaygın bir şekilde kullanılmaktadır. Ayrıca Amerika Gıda ve ilaç yönetimi (FDA) tarafından kurkumin, genel olarak güvenilir ve zararsız olarak kabul edilen "GRAS" olarak onaylanmıştır [23]. Yakın zamanlı çalışmalarla, kurkuminin terapötik etkilerinin günde 4 ila $8 \mathrm{~g}$ arasındaki dozlarda olduğunu rapor edilmişir [24]. Yapılan in vivo ve in vitro çalışmalarla, kurkuminin kanser hücrelerinde, hücre proliferasyonunun inhibisyonu, programlı hücre ölümünün (apoptozis ve otofaji) uyarılması, anjiyogenez ve tümör metaztazının inhibisyonunu sağladığ1 kanıtlanmıştır [25-27]. Chen ve ark. [28], A549 hücre hattında apoptotik biyobelirteçler üzerine yaptıkları çalışmada kurkumin tedavisi sonucunda doza bağlı olarak Bax' da artış gözlemlendiği devamında ise Bcl2'de anlamlı bir azalış gözlemlenmiştir. Bu sonuçların ardından Bcl-2 sevilerindeki azalış mitokondriyal zar potansiyelinde bozulmaya sebebiyet verirken sitokrom-c salınımındaki artış programlı hücre ölümü olan apoptozisi aktive ettiği rapor edilmiştir. Kurkuminin, tek başına veya diğer ajanlarla kombinasyon halinde; apoptotik sinyal yolağının da dahil olduğu çoklu sinyal yolaklarının düzenlenmesi ile anti kanser aktivitesi gösterdiği bildirilmiştir [29-31]. Kurkuminin farklı kanser hücrelerinde mitokondri membran potansiyelini azalttığı ve hücre içi ROS birikimine neden olduğu rapor edilmiştir. Normal hücreler üzerindeki sitotoksisite, geleneksel kemoterapi ve alternatif yaklaşımlar için hala önemli bir sınırlayıcı olarak karşımıza çıkmaktadır. Kemoterapi etkinliğini artırmak için araştırmacılar antineoplastik ajanları, normal hücreler için toksik ve diğer sekonder komplikasyonlara neden olan başka bir ajan ile birlikte denemektedir. Bu bağlamda, normal hücreler için toksik etki göstermeyen doğal moleküller ajanlar ile kemoterapi ajanlarının kombine edilmesi tedavideki sınırlayıcı etmenleri aşmada önemli bir basamak olarak kullanılabileceği öngörülmektedir.

$\mathrm{Bu}$ çalışmamızda; ifosfamid ve kurkumin kombinasyonun A549 akciğer kanseri hücre hattında; hücre proliferasyonu, hücre içi ROS birikimi, hücre göçü ve apoptozisin mitokondriyal yolağında görevli olan Bax ve TIGAR proteinleri üzerindeki etkisinin açıklığa kavuşturulması amaçlanmıştır.

\section{MATERYAL VE METOT}

\subsection{Materyal}

İfosfamid, Baxter Oncology $\mathrm{GmbH}$ Halle (Almanya) firmasından temin edildi. Kurkumin ve 2',7'dichlorofluorescin diacetate (DCFDA) Sigma (Almanya) firmasından satın alındı. RPMI-1640 medium, Fetal sığır serumu (Fetal Bovine Serum; FBS), Penisilin ve Streptomisin karışımı Gibco'dan (Amerika Birleşik Devletleri, ABD) satın alındı. Western blot 
çalışmalarında kullanılan TIGAR ve GAPDH, Santa Cruz Biotechnology (ABD), Bax ve Anti-rabbit antikorları Abcam (Birleşik Krallık) ve Anti-mouse antikoru İnvitrogen (ABD) firmasından temin edilmiştir. Kurkumin, $20 \mathrm{mM}$ 'lik stok solüsyonu hazırlanmak üzere DMSO içerisinde çözdürüldü. Ardından deneylerde kullanılacak dozlar hesaplanarak, besiyerinde çözdürülerek uygulandı. Hücreler, kontrol grubu olarak \%0.1 DMSO ile muamele edildi.

\subsection{Hücre Kültürü Koşulları}

Küçük hücreli olmayan akciğer kanseri hücre hattı A549, ATCC 'den (American type cell culturing) temin edilmiştir. A549 hücrelerinin kültüründe kullanılan besiyerinin temel içeriği RPMI 1640 bazal mediumu, $\% 10$ fetal sığır serumu (FBS) ve \%1 penisilin/streptomisin oluşturmuştur. Hücreler, steril ortamda kültüre edilmiş ve karbondioksitli inkübatörde (\%5 $\mathrm{CO}_{2}$ ve $37^{\circ} \mathrm{C}$ sıcaklık) çoğaltılmıştır.

\subsection{Gerçek Zamanlı Hücre Proliferasyonun Değerlendirilmesi}

A549 hücre hattında, kurkumin ve ifosfamid tedavilerinin hücre proliferasyonu üzerine olan etkileri xCELLigence Real-Time Cell Analyzer (ACEA, San Diego, CA, ABD) cihazı kullanılarak belirlendi. 8 kuyucuklu RTCA-E hücre kültürü plakalarına her kuyucukta 1 x $10^{4}$ hücre olacak şekilde hücre ekildi. Üretici firmanın geliştirdiği protokol takip edilerek hücreler $0,1,2.5,5,10,20,40 \quad \mu \mathrm{M}$ kurkumin ve $0,0.2,0.5,1,5,10,15 \mathrm{mM}$ ifosfamid ile tedavi edildi. Program her 15 dk.'da bir verileri kaydetmek için ayarlandı ve Cell İndex (CI) grafiği elde edildi.

\subsection{Hücre İçi ROS Birikiminin Görüntülenmesi}

A549 hücreleri, 2 × $10^{5}$ hücre/kuyucuk olacak şekilde 6 kuyucuklu hücre kültür kaplarına ekildi. Sonraki gün ilgili ajanlar ile tedavi edildikten sonra 24 saat süre $\mathrm{CO}_{2}$ inkübatöründe inkübe edildi. İnkübasyon sonrasında üç kez PBS ile yıkanıp daha sonra $5 \mu \mathrm{M}$ DCFH-DA ile 30 dakika süreyle karbondioksitli inkübatörde inkübe edildi. Daha sonra hücreler tekrar PBS ile $3 \mathrm{kez}$ yıkandı ve hücrelerin görüntüleri Olympus CKX41 Ters Mikroskop (Olympus, JAPAN) 20X objektif ile kayıt edildi.

\subsection{Protein İzolasyonu ve Western Blot}

Tedavi sonrası kültür kaplarında bulunan hücreler soğuk PBS yıkandıktan sonra kazıcıyıcı yardımıyla kaldırılıp PBS içerisinde mikrosantrifüj tüplerine aktarıldı. Hücreler 10 dakika 6000 rpm'de santrifüjlendi ve süpernatant aspire edilerek ortamdan uzaklaştırıldı. Ardından pelet, proteaz inhibitörlerinin eklendiği soğuk RIPA liziz tamponu ile süspanse edilerek 45 dakika buz üzerinde inkübe edildi. İnkübasyon süresinin ardından $4^{\circ} \mathrm{C}^{\prime}$ de $15,000 \mathrm{rpm}$ 'de 10 dakika santrifüj edildi. Elde edilen süpernatant başka bir tüpe aktarıldı ve Bradford metodu ile örneklerin total protein konsantrasyonları 595 $\mathrm{nm}$ belirlendi. Elektroforez sistemi yardımıla (Bio-Rad Trans-Blot cell, BioRad, ABD), protein örnekleri ve marker SDS-PAGE (\%10-12) jelinde fraksiyonlarına ayrıldı. Ardından jelde ayrilan proteinler Polyvinylidenedifluoride (PVDF) mebrana tarnsfer edildi. Transfer işlemi sonrasında PVDF membran, \%5 yağsız süt tozu içerisinde oda sıcaklığında bir saat inkübe edildi. Akabinde, PVDF membran ilgili primer antikor (üretici firmanın önerdiği dilüsyon oranlarında) ile gece boyunca $+4^{\circ} \mathrm{C}$ 'de çalkalayıcı üzerinde inkübasyona bırakıldı. İnkübasyonun ardından, membran $1 \mathrm{X}$ TBS-T ile $5 \mathrm{dk} / 5 \mathrm{kez}$ yıkandıktan sonra primer antikor ile uyumlu sekonder antikor (üretici firmanın önerdiği dilüsyon oranlarında) ile $60 \mathrm{dk}$ süre ile oda sıcaklığında inkübe edildi. Membran ECL kemilüminesan görüntüleme kiti kullanılarak görüntüler elde edilmiştir. İlgili proteinlere ait bantların yoğunlukları Image-j programı kullanılarak dansitometrik olarak değerlendirilmiştir (Image J; National Institute of Health, Bethesda, MD).

\subsection{Hücre Göçü}

İfosfamid ve kurkumin kombinasyonunun A549 hücreleri göçü üzerine etkilerini araştırmak amacıyla yara iyileşmesi (wound-healing) deneyi gerçekleştirildi. Hücreler, 6 kuyucuklu hücre kültür kaplarına her bir kuyuda $25 \times 10^{4}$ olacak şekilde ekimi gerçekleștirildi. Hücrelerin yüzeye yapışmasının ardından $200 \mu$ l'lik pipet ucu yardımı ile düz bir hat oluşturacak biçimde hücreler kazındı. Kaldırılan hücrelerin yeniden yüzeye yapışmaması için her bir kuyucuk PBS ile iki kez yıkand1. Kurkumin, ifosfamid ve kombinasyonları ile tedavi edildi. Ardından hücrelerin hareketleri izlendi ve her bir kuyucuğun 0 . 24. ve 48. saatlerdeki görüntüleri kaydedildi.

\section{7. İstatistiksel Analiz}

İstatistiksel analiz "One-way ANOVA" metodunda çoklu karşılaştırma Post-Hoc Testlerine göre Graph Pad Prism 5.01 programı ile analiz edilmiştir. Analizlerde $\mathrm{p}$ $<0.05$ önemli olarak kabul edilmiştir.

\section{BULGULAR}

\subsection{A549 Hücre Hattında İfosfamid ve Kurkumin'in Hücre Proliferasyonu Üzerine Etkileri}

Gerçek zamanlı hücre izleme sistemi ile ifosfamid ve kurkuminin A549 hücre proliferasyonuna olan etkisi doz ve zamana bağlı olarak analiz edildi. Kurkumin $(0,1,5$, $10,15,20,40 \mu \mathrm{M})$ ve İfosfamid $(0,1,5,10,15,20,40$ $\mathrm{mM}$ ) ile tedavi edilen hücreler, 24 saat boyunca her 15 $\mathrm{dk}$ bir ölçüm alınarak analiz edildi. Ifosfamid tedavisi ile hücre indeksinde doz bağımlı bir düșüş gözlendi. Öte yandan kurkumin uygulamasından sonra 24 . Saatte hücre indeksi en yüksek doz olan $40 \mu \mathrm{M}$ dişındaki dozlarda anlamlı değişim olmadığı belirlendi (Şekil 1. A ve B). 


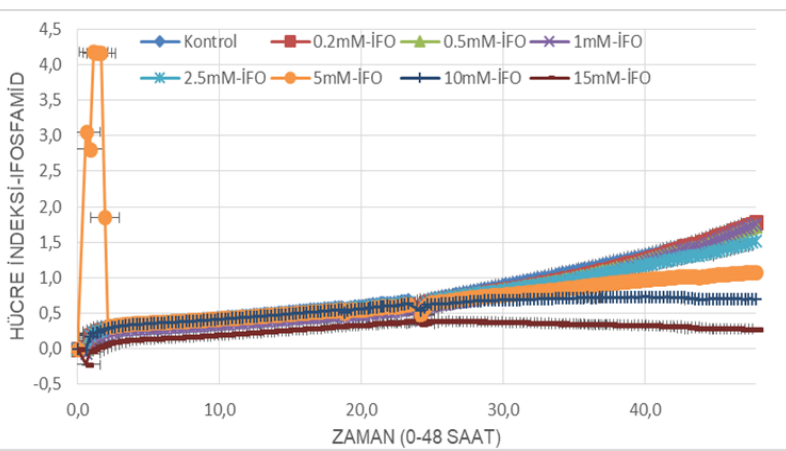

(A)

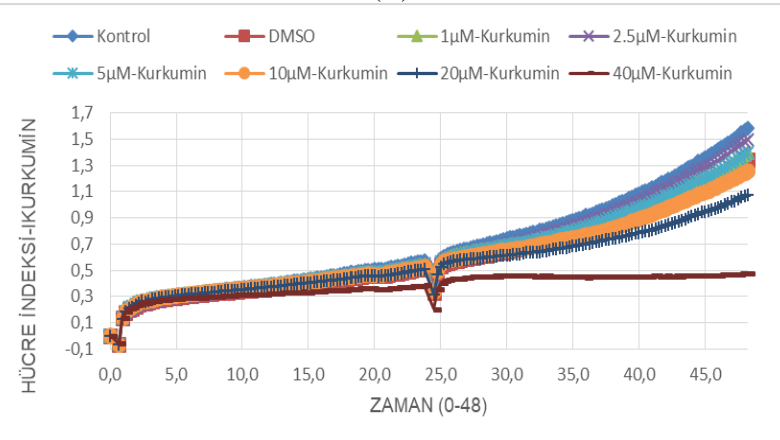

(B)

Şekil 1. İfosfamid (A), Kurkumine (B) maruz bırakılan A549 hücrelerinin gerçek-zamanlı hücre analizi.

\section{2. İfosfamid ve Kurkumin Kombinasyonun Hücre içi ROS Birikimi Üzerine Etkileri}

ROS, hücresel metabolik aktivite, hücre döngüsü, programlı hücre ölümü dâhil olmak üzere birçok hücresel aktivite için anahtar düzenleyici bir faktördür. İfosfamid ve kurkumin kombinasyonun A549 hücre hattında, hücre içi ROS birikimine olan etkisini belirlemek amaciyla floresan DCFDDA probu kullanıldı. Hücreler kurkumin, ifosfamid ve Kombinasyonları ile 24 saatlik tedavi sonrasında floresan ataçmanlı invert mikroskop ile görüntülendi. Hem kurkumin hemde ifosfamid ile tedavi sonrasinda floresan sinyalin kontrol grubuna oranla arttığı belirlendi. Ayrıca kombinasyon grubundaki hücrelerde oluşan floresan sinyalin tek ajan ile tedavi edilen gruplarla karşılaştırıldığında kayda değer ölçüde arttığı tespit edilmiştir (Şekil 2).
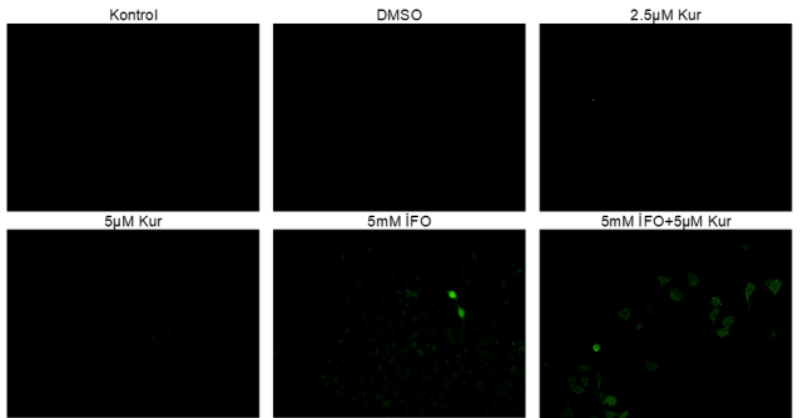

Şekil 2. Kombinasyon tedavisinin hücre içi ROS birikimine olan etkisi Kur, IFO ve IFO/Kur kombinasyonları ile tedavi edilen hücreler DCFDA ile muamele edildikten sonra hücrelerin görüntüleri Ters Mikroskop (20x objektif) ile kayıt edildi.

\section{3 İfosfamid ve Kurkumin Kombinasyonun Pro- apoptotik ve Anti-apoptotik Proteinlerin Ekspresyon Düzeyleri Üzerine Etkisi}

Western blot analizleri sonucunda belirlenen apoptotik proteinine ait ekspresyon düzeyleri Şekil 3'de gösterilmiştir. Pro-apoptotik Bax proteinin ekspresyonunun kontrol grubuna oranla kurkumin grubunda belirgin olarak artış olmadığı gözlemlendi. Öte yandan ifosfamid grubunda ise Bax proteini düzeyinin kontrol grubuna oranla arttığı tespit edildi. Ayrıca kombinasyon grubunda Bax proteinin en yüksek düzeyde olduğu ve istatistiksel olarak kontrol grubundan anlamlı bir şekilde farklı olduğu belirlenmiştir $(p<0,05)$. Anti-apoptotik protein TIGAR'ın ekspresyonun analizlerinde bant yoğunluğunun kontrol grubu ile karşılaştırıldıklarında kurkumin ve ifosfamid gruplarında kayda değer bir farklılığın olmayışı dikkat çekiciydi. Kurkumin ve ifosfamid kombinasyonu ile tedavi edilen grupta ise bu proteinin yoğunluğu kontrol ve tek ajan ile tedavi edilen gruplara göre anlamlı bir düşüş olduğu belirlendi $(p<0,05)$. Kurkumin ve ifosfamid gruplar1 konrol ile benzer, kombinasyon grubu ise diğer tüm gruplardan farklı idi.

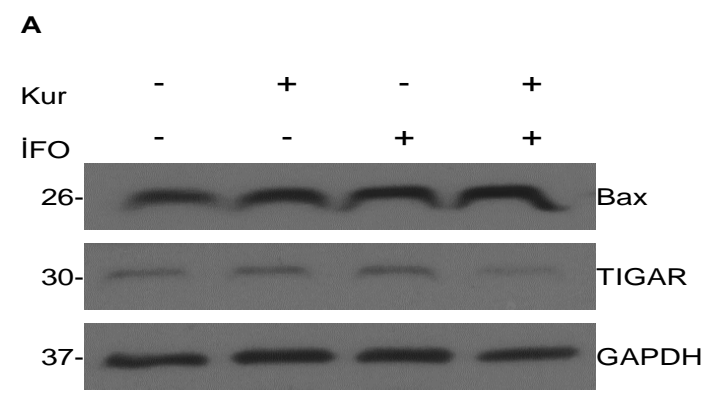

B

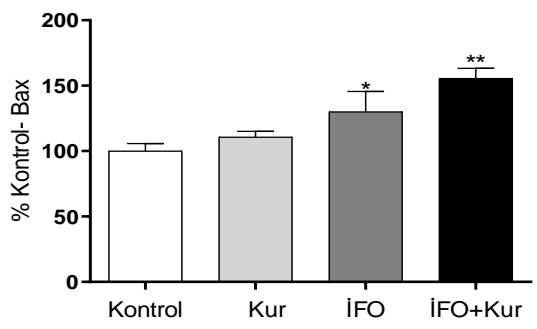

C

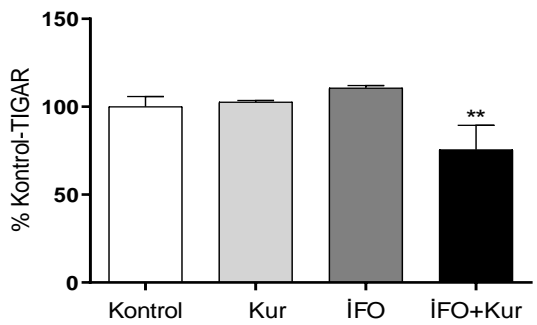

Şekil 3. Kombinasyon tedavisinin Bax ve TIGAR Ekspresyonu Üzerine Etkileri. A) Westsern blot bantları. (Bax, TIGAR ve GAPDH proteinlerinin ekspresyon düzeyleri western blotlama ile tespit edildi. ) B) Bax proteini ekspresyon düzeyleri C)TIGAR proteini ekspresyon düzeyleri. Kontrol olarak GAPDH kullanıldı. Kontrol grubu ile karşılaştırıldığında, $* \mathrm{P}<0.05, * * \mathrm{P}<0.01$. 


\section{4 İfosfamid ve Kurkumin Kombinasyonun Hücre Göçü Üzerine Etkisi}

Yara iyileşmesi deneyinde A549 hücreleri ifosfamid, kurkumin ve kombinasyonları ile tedavi edildikten sonra 24 saatlik aralıklarla incelenmiş ve görüntüleri kaydedilmiştir. Düşük doz $(2.5 \mu \mu \mathrm{M})$ kurkumin uygulanan hücrelerde 24. saatten itibaren kontrol grubuna benzer şekilde hücreler arası boşluğun kapandığı gözlenmiştir. $5 \mu \mathrm{M}$ kurkumin tedavisinde ise 48. saatte kapanmaya başladığı belirlenmiștir. İfosfamid uygulanan hücrelerde ise 0 . saatte $1168 \mu \mathrm{m}$ olan hücreler aras1 mesafenin 48. saatte sonunda 1061,20 $\mu$ m'ye gerilediği belirlenmiştir. En dikkat çekici sonuç ifosfamid ve kurkumin kombinasyonun uygulandığ 1 hücrelerde 48. saatteki hücreler arası mesafenin $(1298,40$ $\mu \mathrm{m})$ 24. saatteki mesafeye $(1312,10 \mu \mathrm{m})$ çok yakın olması idi.

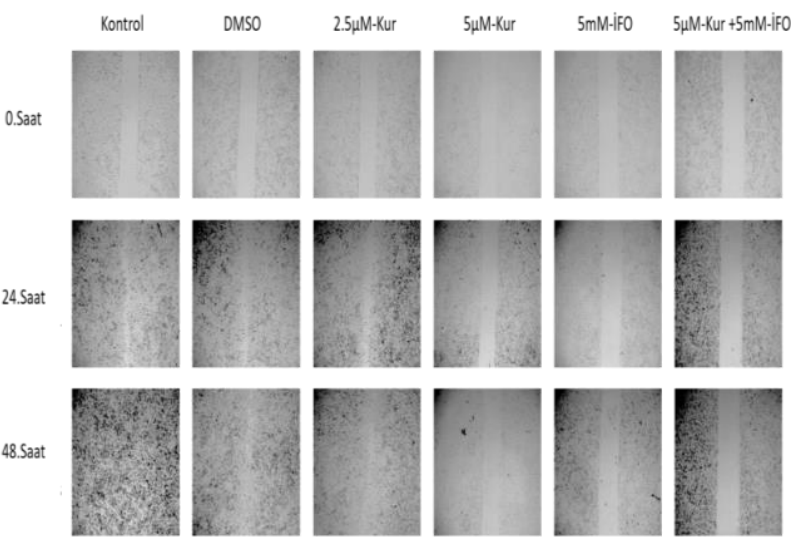

Șekil 4. Kombinasyon tedavisinin hücre göçü üzerine etkisi. Kur, IFO ve IFO/Kur kombinasyonunun A549 hücrelerinde, hücre göçü üzerindeki inhibitör etkisi, yara iyileştirme testi kullanılarak tespit edildi. Tedavi sonrası, hücrelerin 0 . 24. ve 48. saatlerdeki görüntüleri Ters Mikroskop (20x objektif) ile kayıt edildi.

\section{SONUÇ VE TARTIŞMA}

Mevcut çalışmamızda, ifosfamid ve kurkumin'in A549 hücrelerinde, hücre proliferasyonunu inhibe ettiğini, hücre içi ROS birikimine neden olduğunu ve apoptozisi indüklediğini bulduk. Ayrıca ifosfamid ve kurkumin kombinasyonunun, A549 hücresinde hücre göçünü baskıladığını gösterdik. Bulgularımız, mekanistik olarak, ifosfamid ve kurkumin kombinasyonunun, A549 hücrelerinde TIGAR ekspresyonunu aşağı, Bax ekspresyonunu ise yukarı yönlü regüle ederek uyguladığını gösterdi. $\mathrm{Bu}$ sonuçlar, ifosfamid ve kurkumin kombinasyonunun akciğer kanseri tedavisi için etkili olabileceğini ortaya koymuştur.

Son zamanlarda uygulanan kemoterapötik stratejiler, tek bir ajandan daha etkin olduklarına inanılan farklı bileșiklerin kombinasyonun kullanılmasına doğru dönüşmektedir. Kombinasyon tedavi stratejileri, kemoterapötik ajanların daha az kullanılmasının yanı sıra tedavi etkinliklerinin artması ve oluşan yan etkilerin azaltılmasında önemli bir faktör olabilir. İfosfamid, kanser tedavisinde yaygın olarak kullanılan ve iyi bilinen bir kemoterapötik ajandır [15]. Bununla birlikte sisplatin, paklitaksel, dosetaksel ve oksaliplatin gibi diğer kemoterapötik ajanlara benzer şekilde kanser hücrelerinde, İfosfamid'in etkinliğini sınırlayan ilaç direnci ve/veya olumsuz yan etkiler ile karşılaşmak oldukça muhtemel bir sonuçtur. Bu durum, ifosfamid'e karş1 oluşabilecek muhtemel direncini tersine çevirmek ve yan etkilerini azaltmak için farklı stratejilerin kullanılmasını zorunlu kılmaktadır. Fitokimyasalar, çeşitli farmakolojik aktiviteleri nedeniyle bu durumda potansiyel adaylardır. Zerdeçal rizomundan izole edilen Kurkumin'in geniş bir farmakolojik aktivite yelpazesine sahip potansiyel bir antitümör fitokimyasal olduğu bildirilmiştir [29]. Kurkumin'in farklı kanser hücrelerinde, hücre döngüsünün durdurulması ve apoptotik hücre ölümünün de dâhil olduğu farklı yolakları etkileyerek potansiyel kemoterapötik aktiviteye sahip olduğu bildirilmiștir [32]. Yakın zamanlı çalışmalarda, Kurkumin'in, ROS bağlı mitokondriyal sinyal yolağı aracılığında küçük hücreli dışı akciğer kanseri A549 ve NCI-H460 hücrelerinde apoptozisi indüklediği rapor edilmiştir [33], [35]. Klinik öncesi çalışmaların sonuçları, kombinasyon tedavilerinin toksisiteyi neden olmadan antikanser etkinliğini artırdığını göstermektedir [36]. $\mathrm{Bu}$ nedenle, mevcut çalışmamızda ifosfamid ile kombinasyon halinde kurkumin tedavisinin insan akciğer kanseri A549 hücrelerinde, ROS birikimi, apoptotik biyobelirteçler ve hücre göçü üzerine etkilerini araştırmayı amaçladık. Mitokondri, hücre içi ROS üretiminin başlıca kaynağıdır ve hücre içi ROS düzeyi, kanser süreçlerinde çok önemli roller oynamaktadır. Hücre içi ROS, yüksek düzeyde olduğunda oksidatif stresi ve hücre ölümüne yol açan apoptozisi aktive ettiği, düşük düzeyde ise anjiyogenezin aktivasyonu, tümör hücrelerinin yayılmasını ve metastazını başlattığı bildirilmiştir [37]. Son gelişmeler, kurkuminin ROS üreten, oksidatif strese neden olan ve ardından apoptozu indükleyen hücre içi bir pro-oksidan olduğunu açıkça ortaya koymuștur [27]. Hücre içi antioksidanlar arasinda, GSH'ın önemli bir yeri bulunmaktadır. GSH, hücre içinde oksijeni ve diğer serbest radikal türlerini nötralize etmekte önemli bir rol oynar. Chen ve ark. [33] A549 hücreleri üzerinde yaptıkları çalışmalarında kurkumin ve NAC/GSH'1 birlikte uyguladıklarında kurkumin kaynaklı ROS oluşumu üzerinde koruyucu etki gösterdiğini rapor etmişlerdir. Aynı zamanda kullanılan bu anti-oksidanın, mitokondri membran potansiyeli kaybını azalttığını ve kurkumin ile tedavi edilen hücrelerde hücre apoptozunu önlediğini bildirmişlerdir. Issels ve ark. [20], ifosfamidin sitotoksik etkisini, hücre içi GSH düzeyini önemli ölçüde azalmasına yol açarak sağladığını göstermiş̧lerdir. Yapılan bu çalışmalar hem ifosfamid hem de kurkuminin birlikte kullanımının hücre içi ROS birikimine neden olabileceğini düşünmemize neden olmuştur. $\mathrm{Bu}$ nedenle çalışmamızda, ilk olarak, iki pro-oksidan ile yapılacak kombine tedavinin hücre içi ROS birikimi üzerinde bir etkiye sahip olup olmadığını belirlemeyi amaçladık. Bulgularımız, ifosfamid ve kurkuminin birlikte tedavisinin A549 hücre hattında, hücre içi ROS birikiminde önemli bir artışa neden olduğunu göstermiştir. Hücre içi ROS birikimi, ifosfamid ve kurkuminin kombinasyonun ROS aracılı apoptotik yolağı aktive edip-edemeyeceği sorusunu sormamıza neden olmuştur. Yakın zamanlı çalışmalar, kurkuminin, etoposide ve sisplatin gibi anti-kanser ilaçların aktivitesini apoptozu indüklemek ve hücre 
proliferasyonunu inhibe etmek vasıtası ile arttırdığını göstermiştir [38], [39]. Programlanmış bir hücre ölümü olan apoptozis, mitokondri membranın bozulmasının ardından Sitokrom-C'nin sitoplazmaya geçmesi ve kaspaz 3'ün aktive edildiği içsel (intirinsik) ve FAS reseptörünün uyarılması ile başlayan dışsal (ekstrinsik) yolaklarından oluşmaktadır [40]. Apoptozisin regülasyonunun bozulması, tümör gelişiminde çok önemlidir ve Bcl-2 protein ailesi bu süreçte önemli rol oynamaktadırlar [41]. Bcl-2 ailesi, anti-apoptotik (Bcl-2, $\mathrm{Bcl}-\mathrm{xL}$, TIGAR) ve pro-apototik faktörlerden (Bax) oluşmakta ve mitokondriyal yolu etkileyerek hücrelerin apoptotik hücre ölümünü düzenlemektedirler [42]. Bcl-2 ailesini düzenleyen ana protein olan p53, akciğer kanseri hücrelerinde hem mitokondriyal hemde dişsal yolakta önemli rollere sahip olduğu bilinmektedir. Sitoplazmik p53'ün, mitokondri yüzeyine transloke olduktan sonra Bcl-2 ailesi proteinlerine doğrudan bağlanarak, mitokondrinin geçirgenliğini değiştirdiği, pro ve antiapoptotik proteinleri düzenlediği bildirilmiştir [43]. Iffosfamid'in bir metaboliti olan Acr'ye maruz birakılan akciğer kanseri hücrelerinde p53- bağımlı ve bağımsız apoptozisin indüklendiği rapor edilmiştir [18]. Öte yandan, kurkuminin ROS'a bağımlı-mitokondriyal sinyal yoluyla A549 hücrelerinde apoptozisi indüklediği bildirilmiştir [32], [38]. Bu durum, kurkuminin neden olduğu ROS indüksiyonunun ifosfamid'in sitotoksisitesini ve apoptozisi artırma olasılığını ortaya çıkmaktadır. TP53 kaynaklı glikoliz ve apoptozis düzenleyicisi olan TIGAR proteini, transkripsiyon faktörü olan p53'ün hedef geninin ürünüdür. Yapılan çalışmalarda, TIGAR `ın hücre içi NADPH'nın artırması, ROS'un hücre içi ortamdan temizlenmesi ve oksidatif stres aracılı apoptozisin inhibisyonunda görev aldığı bildirilmiştir [44], [45]. Bu çalışmada elde edilen Western Blot sonuçlarına göre, kurkumin ya da ifosfamid ile tedavi edilen hücrelerde TIGAR proteinin ekspresyonununda kayda değer bir değişimin olmadiğ1 tespit edilmiştir. Kurkumin ve ifosfamid'in kombine olarak uygulandığı grupta ise, Bax proteinin aksine TIGAR proteinin düzeyinde dramatik bir azalma olduğu gösterilmiştir. Ayrıca kombinasyon tedavisinin proapoptotik Bax üzerinde güçlü bir ekspresyon artırıcı etkiye sahip olduğu tespit edilmiştir. Hücre içi ROS birikiminin yanı sıra önemli bir ROS düzenleyici ve antiapoptotik protein TIGAR'ın düzeyindeki anlamlı azalış, kurkumin ve ifosfamid kombinasyonun ROS-aracilı apoptozis ile A549 hücrelerinde ifosfamid'in antineoplastik etkisini arttırdığını ortaya koymaktadır. Tümör invazyonu ve metastazı, matriksin bozulması, hücre göçü, proliferasyonu ve anjiyogenezini içeren oldukça karmaşık ve çok aşamalı bir süreçtir [46]. Chen ve ark. [47], kurkuminin akciğer kanseri hücrelerinde hücre invazyonu ve göçünü inhibe ettiğini rapor etmişlerdir. Yapılan bir başka çalışmada, kurkuminin, küçük hücreli dış1 akciğer kanseri hücrelerindeki metastazı, adiponectin/NF-kB/MMP yolakları vasıtası ile inhibe ettiğini bildirmişlerdir [48]. Bu çalışmanın temel bulgularından biride, literatürle uyumlu bir biçimde, kurkuminin A549 hücre hattının hücre göçünü inhibe etmesidir. İfosfamid'in kurkumin ile kombinasyonunun hücre göçünü tek ajan ile tedavi edilen gruplardan daha fazla inhibe etmesi dikkat çekici bir diğer bulgudur. Bu durum, ifosfamid ve kurkuminin kombinasyonun antimetastaz etkilerinin, kısmen, tek ajan tedavisinden daha fazla inhibe edebileceğini göstermektedir. Bu çalışmanın bulguları, ifosfamid ve kurkumin kombinasyonu ile tedavi edilen A549 hücrelerinde ifosfamid ve kurkumin tekli olarak kullanımlarına kıyasla, hücre içi ROS birikiminin arttığını, apoptotik hücre ölümünü indüklediğini ve hücre göçünün önemli ölçüde azalttığını göstermiştir. Sonuçlar, kurkumin ilavesinin ifosfamid'in etkinliğini artırdığını ve daha ileri in vitro çalışmalarla, insan akciğer kanserine karşı tedavi seçenekleri geliştirmek için moleküler yolakların hedeflemesi gerektiğini göstermektedir. Ayrıca ifosfamid ve kurkumin kombinasyonun in vivo çalışmalar ile sorgulanması ve anti-kanser işlevini gösterip göstermediğinin belirlenmesi gerekmektedir.

\section{Teșekkür}

$\mathrm{Bu}$ çalışma TÜBİTAK tarafindan (Proje No: 1919B012000962) desteklenmiştir.

\section{KAYNAKLAR}

[1] Bray F, Ferlay J, Soerjomataram I, Siegel RL, Torre LA, Jemal A. Global cancer statistics 2018: GLOBOCAN estimates of incidence and mortality worldwide for 36 cancers in 185 countries. CA Cancer J Clin. 2018;68(6):394-424.

[2] Siegel RL, Miller KD, Jemal A. Cancer statistics, 2017. CA Cancer J Clin. 2017;67(1):7-30.

[3] Pirker R. Chemotherapy remains a cornerstone in the treatment of nonsmall cell lung cancer. Current opinion in oncology. 2020;32(1):63-7.

[4] Belani CP. Paclitaxel/carboplatin in the treatment of non-small-cell lung cancer. ONCOLOGYWILLISTON PARK THEN HUNTINGTON-. 1998; 12: 74-9.

[5] Emadi A, Jones RJ, Brodsky RA. Cyclophosphamide and cancer: golden anniversary. Nature reviews Clinical oncology. 2009 Nov;6(11):638.

[6] Agca CA, Kırıcı M, Nedzvetsky VS, Gundogdu R, Tykhomyrov AA. The Effect of TIGAR Knockdown on Apoptotic and EpithelialMesenchymal Markers Expression in DoxorubicinResistant Non-Small Cell Lung Cancer A549 Cell Lines. Chemistry \& Biodiversity. 2020;17(9): 1-14.

[7] Dilruba S, Kalayda GV. Platinum-based drugs: past, present and future. Cancer chemotherapy and pharmacology. 2016;77(6):1103-24.

[8] Liu RM, Xu P, Chen Q, Feng SL, Xie Y. A multiple-targets alkaloid nuciferine overcomes paclitaxel-induced drug resistance in vitro and in vivo. Phytomedicine. 2020;79: 1-12.

[9] Huang RY, Pei L, Liu Q, Chen S, Dou H, Shu G, Yuan ZX, Lin J, Peng G, Zhang W, Fu H. Isobologram analysis: a comprehensive review of methodology and current research. Frontiers in pharmacology. 2019 29;10: 1222.

[10] Martín AJM, Alfonso PG, Rupérez AB, Jiménez MM. Nab-paclitaxel plus gemcitabine as first-line palliative chemotherapy in a patient with metastatic 
pancreatic cancer with Eastern Cooperative Oncology Group performance status of 2. Oncol Lett. 2016;12(1):727-30.

[11] Ebara S, Kobayashi Y, Sasaki K, Araki M, Sugimoto M, Wada K, et al. A case of metastatic urachal cancer including a neuroendocrine component treated with gemcitabine, cisplatin and paclitaxel combination chemotherapy. Acta Med Okayama. 2016;70(3):223-7.

[12] Wagner $\mathrm{T}$. Ifosfamide clinical pharmacokinetics. Clinical pharmacokinetics. 1994 Jun;26(6):439-56.

[13] Binotto G, Trentin L, Semenzato G. Ifosfamide and cyclophosphamide: effects on immunosurveillance. Oncology. 2003;65(2):17-20.

[14] Aziz K, Nowsheen S, Pantelias G, Iliakis G, Gorgoulis VG, Georgakilas AG. Targeting DNA damage and repair: embracing the pharmacological era for successful cancer therapy. Pharmacology \& therapeutics. 2012 Mar;133(3):334-50.

[15] Jacot W, Pujol JL, Chakra M, Molinier O, Bozonnat MC, Gervais R, et al. Epirubicin and ifosfamide in relapsed or refractory small cell lung cancer patients. Lung Cancer. 2012;75(2):213-6.

[16] Furlanut M, Franceschi L. Pharmacology of ifosfamide. Oncology. 2003;65(2):2-6.

[17] Wang HT, Chen TY, Weng CW, Yang CH, Tang M. Acrolein preferentially damages nucleolus eliciting ribosomal stress and apoptosis in human cancer cells. Oncotarget. 2016;7(49):80450-64.

[18] Lee L-K, Chen P-M, Tzeng C-H, Liu J-H, Yen CC. Ifosfamide-Induced Fanconi's Syndrome. J Cancer Res Pract. 2014;1(1):46-9.

[19] Issels RD, Meier TH, Müller E, Multhoff G, Wilmanns W. Ifosfamide induced stress response in human lymphocytes. Mol Aspects Med. 1993;14(3):281-6.

[20] Meng B, Li J, Cao H. Antioxidant and Antiinflammatory Activities of Curcumin on Diabetes Mellitus and its Complications. Curr Pharm Des. 2013;19(11):2101-13.

[21] Trujillo J, Chirino YI, Molina-Jijón E, AndéricaRomero AC, Tapia E, Pedraza-Chaverrí J. Renoprotective effect of the antioxidant curcumin: Recent findings. Redox biology. 2013;1(1):448-56.

[22] Agrawal DK, Mishra PK. Curcumin and its analogues: potential anticancer agents. Medicinal research reviews. 2010;30(5):818-60.

[23] Salehi M, Movahedpour A, Tayarani A, Shabaninejad Z, Pourhanifeh MH, Mortezapour E, et al. Therapeutic potentials of curcumin in the treatment of non-small-cell lung carcinoma. Phyther Res. 2020;34(10):2557-76.

[24] Hewlings S, Kalman D. Curcumin: A Review of Its Effects on Human Health. Foods. 2017;6(10):92.

[25] Chen L, Zhan C-Z, Wang T, You H, Yao R. Curcumin Inhibits the Proliferation, Migration, Invasion, and Apoptosis of Diffuse Large B-Cell Lymphoma Cell Line by Regulating MiR-21/VHL Axis. Yonsei Med J. 2020;61(1):20.

[26] Sak K. Radiosensitizing potential of curcumin in different cancer models. Nutrition and cancer. 2020;72(8):1276-89.
[27] Zhu Y, Bu S. Curcumin induces autophagy, apoptosis, and cell cycle arrest in human pancreatic cancer cells. Evidence-Based Complementary and Alternative Medicine. 2017; 4: 1-13.

[28] Chen QY, Lu GH, Wu YQ, Zheng Y, Xu K, Wu $\mathrm{LJ}$, et al. Curcumin induces mitochondria pathway mediated cell apoptosis in A549 lung adenocarcinoma cells. Oncol Rep. 2010;23(5):1285-92.

[29] Devassy JG, Nwachukwu ID, Jones PJH. Curcumin and cancer: Barriers to obtaining a health claim. Nutr Rev. 2015;73(3):155-65.

[30] Hu A, Huang J-J, Zhang J-F, Dai W-J, Li R-L, Lu $\mathrm{Z}-\mathrm{Y}$, et al. Curcumin induces G2/M cell cycle arrest and apoptosis of head and neck squamous cell carcinoma in vitro and in vivo through ATM/Chk2/p53-dependent pathway. Oncotarget. 2017;8(31):50747-60.

[31] Guan F, Ding Y, Zhang Y, Zhou Y, Li M, Wang C. Curcumin suppresses proliferation and migration of MDA-MB-231 breast cancer cells through autophagy-dependent Akt degradation. PLoS One. 2016;11(1):1-18.

[32] Tan BL, Norhaizan ME. Curcumin combination chemotherapy: The implication and efficacy in cancer. Molecules. 2019;24(14):1-21.

[33] Chen Q, Wang Y, Xu K, Lu G, Ying Z, Wu L, et al. Curcumin induces apoptosis in human lung adenocarcinoma A549 cells through a reactive oxygen species-dependent mitochondrial signaling pathway. Oncol Rep. 2010;23(2):397-403.

[34] Yanagawa H, Haku T, Takeuchi E, Suzuki Y, Nokihara H, Sone S. Intrapleural therapy with MDP-Lys (L18), a synthetic derivative of muramyl dipeptide, against malignant pleurisy associated with lung cancer. Lung Cancer. 2000;27(2):67-73.

[35] Wu SH, Hang LW, Yang JS, Chen HY, Lin HY, Chiang $\mathrm{JH}$, et al. Curcumin induces apoptosis in human non-small cell lung cancer NCI-H460 cells through ER stress and caspase cascade- and mitochondria-dependent pathways. Anticancer Res. 2010;30(6):2125-33.

[36] Yue Q, Gao G, Zou G, Yu H, Zheng X. Natural products as adjunctive treatment for pancreatic cancer: recent trends and advancements. BioMed research international. 2017 23;4: 1-13.

[37] Aggarwal V, Tuli HS, Varol A, Thakral F, Yerer $\mathrm{MB}$, Sak K,et al. Role of reactive oxygen species in cancer progression: molecular mechanisms and recent advancements. Biomolecules. 2019;9(11):735.

[38] Chanvorachote P, Pongrakhananon V, Wannachaiyasit S, Luanpitpong S, Rojanasakul Y, Nimmannit U. Curcumin sensitizes lung cancer cells to cisplatin-induced apoptosis through superoxide anion-mediated Bcl-2 degradation. Cancer Invest. 2009;27(6):624-35.

[39] Papież MA, Krzyściak W, Szade K, BukowskaStraková K, Kozakowska M, Hajduk K, et al. Curcumin enhances the cytogenotoxic effect of etoposide in leukemia cells through induction of reactive oxygen species. Drug Des Devel Ther. 2016; 10: 557-70. 
[40] Jayakiran M. Apoptosis-Biochemistry: A Mini Review. J Clin Exp Pathol. 2015;05(01):1-4.

[41] Tiwari P, Khan MJ. Molecular and computational studies on apoptotic pathway regulator, $\mathrm{Bcl}-2$ gene from breast cancer cell line MCF-7. Indian J Pharm Sci. 2016;78(1):87-93.

[42] Nakazawa M, Matsubara H, Matsushita Y, Watanabe M, Vo N, Yoshida H, et al. The human Bcl-2 family member Bcl-rambo localizes to mitochondria and induces apoptosis and morphological aberrations in drosophila. PLoS One. 2016; 11(6) 1-23.

[43] Liu G, Pei F, Yang F, Li L, Amin AD, Liu S,et al. Role of autophagy and apoptosis in non-small-cell lung cancer. International journal of molecular sciences. 2017;18(2):367.

[44] Bensaad K, Cheung EC, Vousden KH. Modulation of intracellular ROS levels by TIGAR controls autophagy. EMBO J. 2009;28(19):3015-26.

[45] Bensaad K, Tsuruta A, Selak MA, Vidal MNC, Nakano K, Bartrons R, et al. TIGAR, a p53Inducible Regulator of Glycolysis and Apoptosis. Cell. 2006;126(1):107-20.

[46] Wan Mohd Tajuddin WNB, Lajis NH, Abas F, Othman I, Naidu R. Mechanistic Understanding of Curcumin's Therapeutic Effects in Lung Cancer. Nutrients. 2019;11(12):2989.

[47] Chen Q yong, Zheng Y, Jiao D min, Chen F yuan, $\mathrm{Hu} \mathrm{H}$ zhen, Wu Y quan, et al. Curcumin inhibits lung cancer cell migration and invasion through Rac1-dependent signaling pathway. J Nutr Biochem. 2014;25(2):177-85.

[48] Tsai JR, Liu PL, Chen YH, Chou SH, Cheng YJ, Hwang JJ, et al. Curcumin inhibits non-Small cell lung cancer cells metastasis through the adiponectin/nf-kb/mmps signaling pathway. PLoS One. 2015 Dec 1;10(12). 